\title{
Investigation of Streptococcus agalactiae Colonization inThe Last Trimester Pregnants by Using Standard Culture and Molecular Methods
}

Özgün Araştırma Research Article

Received/Geliş: 28.12.2019 Accepted/Kabul: 06.02.2020 Published Online: 29.04.2021

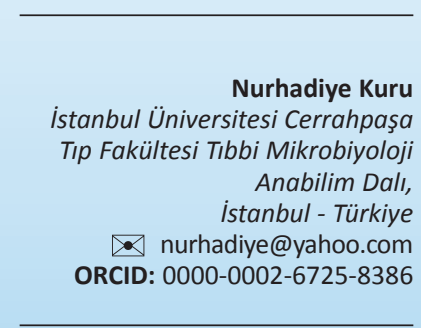

N. Gonullu 0000-0003-4289-1975 Istanbul Üniversitesi Cerrahpaşa Tıp Fakültesi Tıbbi Mikrobiyoloji Anabilim Dalı, istanbul, Türkiye

O. Kuru 0000-0002-4497-7222 Tepecik Eğitim ve Arastırma Hastanesi, Kadın Hastalıkları ve Doğum Jinekolojik Onkoloji Ünitesi, İmir, Türkiye

A. Tüten 0000-0002-8495-6426 istanbul Üniversitesi Cerrahpaşa Tıp Fakültesi Kadın Hastalıkları ve Doğum Anabilim Dalı, Istanbul, Türkiye

This study was accepted as poster presentation at ASM Microbe 2016 in Boston, Massachusetts, June 16-20, 2016.

Cite as: Kuru N, Kuru O, Tüten A, Gönüllü $\mathrm{N}$. Investigation of streptococcus agalactiae colonization in the last trimester pregnants by using standard culture and molecular methods. Tepecik Eğit. ve Arașt. Hast. Dergisi. methods. Tepecil

\author{
Son Trimester Gebelerde Streptococcus agalactiae \\ Kolonizasyonunun Standart Kültür ve Moleküler \\ Yöntemler ile Araştırılması
}

\section{ABSTRACT}

Amaç: Üçüncü trimesterdeki gebelerde grup B streptokok (GBS) kolonizasyonunu gerçek zamanlı polimeraz zincir reaksiyonu (real-time $P C R$ ) ve kültür yöntemleri kullanarak tespit etmeyi ve bu yöntemleri karşılaştırmayı amaçladık.

Yöntem: Mayıs 2014-Eylül 2014 tarihleri arasında Cerrahpaşa Tıp Fakültesi Kadın Doğum Anabilim Dalı Polikliniğine 35-37. gebelik haftaları arasında başvuran 100 kadından GBS taraması için vajinal swab örnekleri alındı.

Bulgular: GBS kolonizasyon oranlarl; kültür ve real-time PCR yöntemleriyle sırasıyla \% 5 ve \% 7 idi. Kültür altın standart kabul edildiğinde gerçek zamanlı PCR için duyarlılık ve özgüllük sırasıyla \% 100 ve \% 97,9 idi. GBS kolonizasyonu ile yaş grupları, eğitim düzeyleri, önceki gebelik sayıları, sigara içme alışkanlıkları, antibiyotik kullanım öyküsü ve kontraseptif yöntemleri arasında anlamlı bir fark yoktu.

Sonuç: Gerçek zamanlı PCR tekniğinin kültür yöntemi kadar duyarlı olduğu kanıtlanmıştır. Ayrıca, gerçek zamanlı $P C R, G B S$ tespitinde hızlı bir tanı yöntemi olarak daha etkili bir intrapartum antibiyotik profilaksisi sağlar. Bu sayede infantlarda morbidite ve mortalitenin düşük olmasına yardımcı olur. Fakat, PCR testinin her laboratuarda kullanılamaması ve yüksek maliyeti handikap oluşturmaktadır.

Anahtar kelimeler: S.agalactiae, gebelik, kolonizasyon

\section{öz}

Objective: We aimed to detect and compare group B streptococcus (GBS) colonization in pregnant women at third trimester using real-time polymerase chain reaction (real-time PCR) and culture methods.

Methods: Vaginal swab specimens were taken for screening of GBS from 100 women between 35-37 weeks of gestation who were attending to antenatal outpatient unit of Obstetrics and Gynecology Department of Cerrahpasa Medical Faculty from May 2014 to September 2014.

Results: Rates of GBS colonization was $\% 5$ and $\% 7$ by culture and real-time PCR methods, respectively. Using culture as the gold standard; sensitivity and specificity for real-time PCR were 100\% and 97.9\%, respectively. Any significant difference was not detected between GBS colonization with age groups, education levels, number of previous pregnancies, smoking habits, history of antibiotic use, and contraceptive method.

Conclusion: Real-time PCR technique has proven to be as sensitive as the culture method. Also, real-time PCR may provide a rapid diagnostic tool for GBS detection potentially allowing a more effective intrapartum antibiotic prophylaxis and lower infant morbidity and mortality. However, the inability to use PCR test in every laboratory and its high cost creates a handicap.

Keywords: S.agalactiae, pregnancy, colonization
(C) Telif hakkı T.C. Sağık Bakanlığı İzmir Tepecik Eğit. ve Araşt. Hastanesi. Logos Tıp Yayıncllk tarafindan yayınlanmaktadır. Bu dergide yayınlanan bütün makaleler Creative Commons Attf-GayriTicari 4.0 Uluslararası Lisansı ile lisanslanmıştr. (c) Copyright Association of Publication of the T.C. Ministry of Health İmir Tepecik Education and Research Hospital. This journal published by Logos Medical Publishing. Licenced by Creative Commons Attribution-NonCommercial 4.0 International (CC BY) 


\section{INTRODUCTION}

Group B streptococcus (GBS) is a leading cause of sepsis, menengitis, and death among newborns ${ }^{(1,2)}$. GBS colonization in pregnant women is the most important risk factor. As many as $40 \%$ of all pregnant women have rectal and/or vaginal GBS colonization. The incidence of neonatal GBS infection is 0.5 per 100 live births. Vertical transmission from mother to the neonate accounts for up to $75 \%$ of the cases with neonatal GBS colonization, and $1 \%$ to $2 \%$ of these infants will develop early-onset GBS infection ${ }^{(2,3) \text {. }}$

Since 2002, the Center for Disease Control and Prevention $(C D C)$ recommends GBS screening for pregnant women using culture-based method. This approach is preferable, resulting in more effective prevention than clinically risk-based chemoprophylaxis (4). The standard method for the diagnosis of GBS colonization consists of simultaneous culturing of both vaginal and anal swabs in a selective broth medium that inhibits the growth of non-GBS microorganisms. Unfortunately, although the standard culture is a highly sensitive and specific method, it requires 48 hours for complete identification of GBS. Moreover, negative culture results are observed in some women whose infants subsequently develop GBS infection ${ }^{(5-10)}$.

A rapid test that could accurately detect GBS carriage at the time of labour may be an ideal component of a screening programme. Many techniques have been tested in order to validate a fast and efficient method of GBS screening to replace the culture. Nowadays, molecular biology- based assays, such as polymerase chain reaction (PCR), have become the focus of investigation of GBS colonization in pregnant women. A good target for GBS amplification is the $c f b$ gene because it is well studied in this species ${ }^{(11,12)}$. In 2004, FDA approved a realtime PCR method for the identification of GBS in vaginal, and rectal samples ${ }^{(13)}$.
Our prospective study was designed to detect and to compare GBS colonization in pregnant women at third trimester using real-time PCR and culture methods.

\section{MATERIAL and METHOD}

\section{Samples and Microbiological Tests}

After the ethics committee approval was obtained for the study, vaginal swab specimens from 100 women between 35-37 weeks of gestation who were attending to antenatal outpatient unit of Obstetrics and Gynecology Department of Cerrahpasa Medical Faculty were obtained for screening of GBS from May 2014 to September 2014. Two vaginal swabs for each woman were collected from distal $1 / 3$ of the vagina by a trained gynecologist and were transferred to the microbiology laboratory of Cerrahpaşa Faculty of Medicine. Culture swabs were placed in selective enrichment culture media (Todd-Hewitt Broth) and incubated for $24-48$ hours at $37^{\circ} \mathrm{C}$, and then subcultured onto Columbia CNA agar plates which were again incubated at $37^{\circ} \mathrm{C}$ for $24-48$ hours. After incubation, the plates were inspected for the presence of $\beta$-hemolytic colonies. When $\beta$-hemolytic colonies were observed after 24 hours, gram staining was performed. The $\beta$-hemolytic colonies whose morphology was consistent with group B streptococci were subjected to the catalase test. For the catalase-negative suspected colonies, additional tests as bacitracin (Oxoid) and trimethoprim/sulfamethoxazole (Oxoid) resistance tests, CAMP test (standard strain Staphylococcus aureus ATCC 25923), bile-esculine test, PYR (L-pyrrolidonyl-beta-naphtylamide, Oxoid) test were performed to identify GBS. Latex agglutination test (Avipath-Strep, Omega Diagnostics, United Kingdom) was also done to confirm the GBS origin.

\section{Polymerase Chain Reaction}

DNA test was based on real-time PCR assay targeting $c f b$ gene region. DNA samples were extracted using Instagen Matrix (Bio-Rad, USA), according to a proto- 
col explained below:

1-Samples (Cophan Regular Swap and Medium) were transferred from $1000 \mathrm{ul}$ medium to $1.5 \mathrm{ml}$ Eppendorf tube. Then, tubes were centrifugated at $13000 \mathrm{rpm}$ for 10 minutes, and supernatant was removed.

2-A $100 \mu \mathrm{l}$ of InstaGen matrix (Bio-Rad, USA) was added to the pellet and vortexed for $10 \mathrm{~s}$. Each sample was incubated at $99^{\circ} \mathrm{C}$ for $20 \mathrm{~min}$ in mixer heat block unit.

3-The samples were centrifuged at $13000 \mathrm{rpm}$ for 5 min. The DNA containing supernatant was used in the PCR assay.

CFX-96 real-time PCR system (Bio-Rad, Hercules, CA, USA) was used for the thermocycling and fluorescence detection. The real-time PCR amplification was performed in a total volume of $20 \mu$ that contained $10 \mu$ of Seegene Universal PCR Master Mix, 2 $\mu \mathrm{l}$ of primer, $3 \mu \mathrm{l}$ of template DNA and $5 \mu \mathrm{l}$ of ddH2O. The primers used for PCR were as follows, with forward primer 5'TTTCACCAGCTGTATTAGAAGTA3' and reverse primer 5' GTTCCCTGAACATTATCTTTGAT3'. The cycling program was as follows: one cycle at $95^{\circ} \mathrm{C}$ for 15 minutes, 40 cycles at $95^{\circ} \mathrm{C}$ for $15 \mathrm{sec}-$ onds, $60^{\circ} \mathrm{C}$ for 30 seconds and $72^{\circ} \mathrm{C}$ for 30 seconds. One positive control (Streptococcus agalactiae; Kuen 1362, 81/50, KÜKENS) and one negative control were included in each run.

\section{Statistical Analysis}

Statistical analyses were performed using Statistical Package for the Social Sciences (SPSS) software (version 22; SPSS Inc., Chicago, IL, USA). In this study descriptive analyses were used mostly but categorical variables were evaluated using $\chi^{2}$ test or Fisher's Exact test. A p-value $<0.05$ was considered as statistically significant.

\section{RESULTS}

The mean age of the pregnant women in our study was 29.7. \pm 5.56 (range: 19 to 44 ) years. Ninety-one
(91\%) pregnant women had no smoking history while $9(9 \%)$ of them were smokers. None of the pregnants had a history of alcohol use. When the previous contraception methods were questioned; 57 pregnant women (57\%) had not used any method while the remaining pregnants preferred condoms (n:27), pills ( $n: 11)$, and intrauterine devices (IUD: $\mathrm{n}: 5)$. Of the pregnant women, 18 (18\%) had a history of antibiotic use within 2 weeks before delivery.

In our study, GBS colonization was detected in 7 (7\%) pregnant women. GBS growth was detected in the culture of $5(5 \%)$ vaginal swab samples taken from pregnant women. In the real-time PCR test, GBS growth was detected in 7 (7\%) specimens, and also in 2 swab samples where GBS growth was not revealed in the culture. Finally, using culture as the gold standard, sensitivity and specificity for real-time PCR were $100 \%$ and $97.9 \%$, respectively (Table 1 ).

Table 1. Comparison between culture and real time PCR for detection of GBS in vaginal swabs of 100 pregnant women at their 35-37 gestational weeks.

\begin{tabular}{llllc}
\hline & \multicolumn{3}{c}{ Culture } \\
\cline { 2 - 4 } & & Negative & Positive & Total \\
\hline \multirow{2}{*}{ Real - time PCR } & Negative & $93(97.9)$ & $0(0)$ & 93 \\
\multirow{2}{*}{ Total } & Positive & $2(2.1)$ & $5(100)$ & 7 \\
& & 95 & 5 & 100 \\
\hline
\end{tabular}

When the age groups were compared in terms of GBS carriage, GBS positivity in the 21-25 age group $(11 \%, 2 / 18)$ was found to be two times higher than the total positivity in the other age groups $(5 / 82,6 \%)$ but without any statistically significant integroup difference $\left(\chi^{2}: 1.954, p=0,744\right)$. Although GBS colonization was found to be less common in women who had first pregnancy, no statistically significant difference was found between the number of pregnancies and colonization $\left(\chi^{2}: 2.192, p=0.533\right)$. Although GBS colonization rate was higher in smokers ( $11 \%$ vs $6 \%$ ), but without any statistically significant difference when compared with nonsmokers (Fisher's test; $\mathrm{p}: 0.447)$. Although GBS growth was not detected in IUD users, no statistically significant difference was 
found when compared with other groups $\left(\chi^{2}: 0.457\right.$, $p=0.938)$. Also, when the relationship between antibiotic use and GBS colonization was examined, any statistically significant difference was not found between smokers, and nonsmokers $\left(\chi^{2}: 0.724\right.$, $\mathrm{p}=0.855)$. In addition, there was no statistically significant difference between education status of pregnant women and GBS colonization $\left(\chi^{2}: 4.667\right.$ $p=0.332)$.

When newborn results were evaluated; mean gestational age was $38.75 \pm 1.5$ weeks and the mean gestational weight was $3332 \pm 483$ gr. There was no statistically significant difference between GBS and birth weight/gestational week ( $p>0.05)$. On the postnatal $7^{\text {th }}$ day and third month follow-up of newborns; none of the infants had any complication(s).

\section{DISCUSSION}

In our study, we studied real-time PCR method which was an alternative to classical culture method in the antenatal diagnosis of GBS. As a result of the study, GBS carriage was found to be $5 \%$ and $7 \%$ by culture and real-time PCR methods, respectively. Our GBS colonization rate was similar to the previous publications in our country, although it was below the rates cited in the current literature (15-20\%) ${ }^{(14-16)}$. In a study from Turkey, 500 pregnant women were examined at a Training and Research Hospital, and GBS colonization was found to be $8 \%$ in rectovaginal specimens. Infants of 41 mothers colonized with GBS were followed up twice at the first week and third month after delivery and no complication was found in any of the infants ${ }^{(16)}$. Similarly, in our study, there was no complication in infants of GBS colonized mothers. In both clinics, undetected GBS neonatal infection could be explained by antibiotic prophylaxis due to intrapartum clinical risk factors, planned cesarean deliveries and low GBS colonization rate throughout the country.

Different reports about GBS carriage rate are linked to various factors such as race, geographic region, age, smoking, number of pregnancies, contraception method, sexual intercourse pattern, diagnostic method (culture, molecular method, etc) and gestational week, area of the sampling (vaginal and/or rectal) ${ }^{(17,18)}$. Colonization rate increases with parity and decreases with age ${ }^{(19)}$. In our data, no significant relationship was found between the number of pregnancies, age groups and GBS colonization. In a study which examined smoking and GBS colonization it was shown that colonization rate was two times higher in smokers. The reason for this difference may be the role of the suppression of the immune system with the similar mechanism of increased colonization seen in immune compromised patients ${ }^{(20)}$. In our study, GBS colonization was found to be - though not statistically significant- higher in smokers. The use of IUD which is one of the controversial factors of GBS colonization, was investigated by Farrag et al. (21). According to this, colonization rate was found to be significantly higher in patients with IUD users (31\%) compared to non-users (14.5\%). In our study, although GBS growth was not detected in IUD users, it was not statistically significant since GBS colonization rate was low.

Although CDC recommends taking a vaginorectal specimen, rectal sampling may be a problem for pregnant women. In a study from Egypt, none of the pregnants gave permission for rectal sampling ${ }^{(22)}$. In our study, we only took vaginal samples.

One of the factors affecting the colonization of GBS is the media used which increase the chance of isolation by up to $50 \%{ }^{(23)}$. In the same Egyptian study, the diagnostic sensitivity of GBS, which was $50 \%$ in direct culture, increased up to $90 \%$ after subculturing with Lim broth ${ }^{(22)}$. The most important reason for the decrease of sensitivity by direct incubation on the selective plaque is the effect of other bacteria that are overgrown because of weak colonization of GBS (19). 
Although PCR method is a highly sensitive method in GBS screening, a wide range of sensitivity has been reported according to the device and sampling methodology used. Bergeron et al. (23) showed an increase of $62 \%$ PCR-positivity with the Light-Cycler PCR method compared to the culture. A GBS PCR method with the GeneXpert assay, which was also approved by FDA, was found to be $95 \%$ sensitive in the detection of intrapartum GBS carriage ${ }^{(24)}$. In the study of Rallu et al. ${ }^{(11)}, 605$ vaginorectal specimens were examined; 2 different PCR tests analyzing 2 different regions ( $c f b$ and $s c p B$ ) and GBS antigen tests were compared with the standard culture. According to this study, the most accurate results were obtained by scp B PCR test (sensitivity $99.6 \%$; specificity $100 \%$ ), followed by $c f b$ PCR test (sensitivity $75.3 \%$, specificity $100 \%$ ) compared to GBS antigen identification test (sensitivity 57.3\%; specificity $99.5 \%$ ) and the standard culture method (sensitivity $42.3 \%$; specifity $100 \%)$. In the literature, rates of sensitivity were reported as $92-99 \%$ for PCR and $62-98 \%$ for non-enriched samples compared to culture ${ }^{(11)}$. In our data, the rates of sensitivity, and specificity of PCR were $100 \%$ and $97.9 \%$, respectively. An issue that should be discussed is to accept the culture method as the gold standard. Factors such as antibiotic repression, weak GBS colonization, enterococcal growth, contamination, female hygiene products cause PCR positivity and culture negativity. To accept the clinical infection as the gold standard may be a solution. But, unfortunately no newborn infection was observed in our study.

Another important issue is the cost of the tests used. In the study of Picchiassi et al. ${ }^{(25)}$, it was showed that intrapartum PCR test was more expensive than antepartum culture. However its cost may be reduced if the test is widely practiced in the next years. In our study, cost analysis was not performed.

\section{CONCLUSION}

Our results have indicated that PCR technique proved to be as sensitive as the culture method. Also, realtime PCR may provide a rapid diagnostic tool for GBS detection potentially allowing a more effective intrapartum antibiotic prophylaxis and lower infant morbidity and mortality. On the other hand, the inability to use PCR test in every laboratory and its high cost creates a handicap.

Declaration of interest:

None.

Acknowledgements:

None.

Ethics Committee Approval:Approval was obtained from the Ethics Committee of Istanbul University Cerrahpaşa Medical Faculty (12.11.2013/A-03).

Conflict of Interest: The authors declare that they have no conflict of interest.

Funding: This work was supported by Scientific Research Project Coordination Unit of İstanbul University. Project number: 21378.

Informed Consent: Informed consent was obtained.

\section{REFERENCES}

1. Verani JR, McGee L, Schrag SJ. Prevention of perinatal group B streptococcal disease-revised guidelines from CDC, 2010, MMWR Recomm Rep 2010;19(59):1-36.

2. Bakers CJ, Edwards MS. Infectious diseases of the fetus and newborn infant 5. baskı, s.1093-156, 'WB Saunders, Philadelphia 2001.

3. Edwards MS, Baker CJ. Streptococcus agalactiae, "Mandell GR, Bennett CE, Dolin R (eds): Mandels, Douglas and Bennet's Principals and Practice of Infectious Diseases, 5. baskı" kitabında s.2156-67, Churchill Livingstone, New York (2000).

4. Committee on Infectious Diseases, Committee on Fetus and Newborn, Policy statement: Recommendations for the prevention of perinatal group B streptococcal (GBS) disease, Pediatrics 2011;128(3):611-6.

5. Eren A, Küçükercan M, Oğuzoğlu N, Unal N, Karateke A. The carriage of group B streptococci in Turkish pregnant women and its transmission rate in newborns and serotype distribution, Turk J Pediatr 2005;47(1):28-33.

6. Arısoy AS, Altınışık B, Tunger $O$, Kurutepe $S$, Ispahi C. Maternal carriage and antimicrobial resistance profile of group $B$ streptococcus, Infection 2003;31(4):244-6.

7. Yenişehirli G. Bulut Y, Demirtürk F, Çalışkan AC. Gebe kadınlardan izole edilen Streptococcus agalactiae suşlarının antimikrobiyal duyarlılıkları ve serotip dağılımı, Mikrobiyol Bült 2006;40:155-60.

8. Kadanalı, A, Altoparlak Ü, Kadanalı S. Maternal carriage and neonatal colonization of group $B$ streptococcus in eastern 
Turkey: prevalence, risk factors and antimicrobial resistance, Int J Clin Pract 2005;59(4):437-40. [CrossRef]

9. American College of Obstetricians and Gynecologists. ACOG Committee Opinion: Prevention of early-onset group B streptococcal disease in newborns. Obstet Gynecol 2002;100(6):1405-12.

10. Karadeniz M, Akın Y, Ekmekçioğlu $Y$ ve ark. Gebelerde ve yenidoğan bebeklerde Grup B Streptokok sıklığının araştırılması, Kartal Devlet Hastanesi Tıp Dergisi. 1998;9:683-6.

11. Rallu F, Barriga P, Scrivo C, Martel-Laferriere V, Laferriere C. Sensitivities of Antigen Detection and PCR Assays Greatly Increased Compared to That of the Standard Culture Method for Screening for Group B Streptococcus Carriage in Pregnant Women, Journal of Clinical Microbiology 2006;44(3):725-8.

12. Dmitriev A, Suvorov A, Shen AD, Yang YH. Clinical diagnosis of group B streptococci by $\operatorname{scp} B$ gene based PCR, Indian J Med Res. 2004;119:233-6.

13. Alfa MJ, Sepehri S, Gagne PD, Sandhu G, Harding GKM. Real-time $\mathrm{PCR}$ assay provides reliable assessment of intrapartum carriage of GBS, J Clin Microbiol. 2010; 48(9):3095-9. [CrossRef]

14. Hakansson S, Axemo P, Bremme K, et al. Group B streptococcal carriage in Sweden: a national study on risk factors for mother and infant colonisation, Acta Obstet Gynecol Scand. 2008;87(1):50-8. [CrossRef]

15. Convert M, Martinetti LG, Dolina M, Piffaretti JC. Comparison of LightCycler PCR and culture for detection of group B streptococci from vaginal swabs, Clin Microbiol Infect. 2005;11(12):1022-6. [CrossRef]

16. Keven MC. Son Trimester Gebelerde, Rektovajinal Florada Grup B Streptekok Taşıyıcılığı Sıklığı ve Antibiyotik Duyarlıı̆̆ının Araştırılması, Sağlık Bakanlığı, Bakırköy Doğumevi Kadın ve Çocuk Hastalıkları Eğitim ve Araştırma Hastanesi, Kadın Hastalıkları ve Doğum Kliniği Uzmanlık Tezi,
İstanbul (2005).

17. Whitney CG, Daly S, Limpongsanurak $S$, et al. The international infections in pregnancy study: group B streptococcal colonization in pregnant women, J Matern Fetal Neonatal Med. 2004;15(4):267-74. [CrossRef]

18. Meyn LA, Moore DM, Hillier SL, Krohn MA. Association of sexual activity with colonization and vaginal acquisition of group B streptococcus in nonpregnant women, Am J Epidemiol. 2002;155(10):949-57. [CrossRef]

19. Schuchat A, Wenger JD. Epidemiology of group B streptococcal disease. Risk factors, prevention strategies, and vaccine development, Epidemiol Rev. 1994;16(2):374-402. [CrossRef]

20. Terry RR, Kelly FW, Gauzer C, Jeitler M. Risk factors for maternal colonization with group B beta-hemolytic streptococci, J Am Osteopath Assoc. 1999;99(11):571-3. [CrossRef]

21. Farrag OA, Gawad AA, Antar S. Group B-beta haemolytic streptococcal colonization in women using intrauterine contraceptive devices, Contraception. 1985;31(6):595-602. [CrossRef]

22. Wali IE, Sorour AE, Abdalla MAH. Assessment of Different Methods for Detection of Group B Streptococci carriage among Pregnant Females, Egyptian Journal of Medical Microbiology. 2007;16(4):593-8.

23. Bergeron MG, Ke D, Menard $C$, et al. Rapid detection of group B streptococci in pregnant women at delivery, N Engl J Med. 2000;343(3):175-9. [CrossRef]

24. Gavino M, Wang EA. comparison of a new rapid real-time polymerase chain reaction system to traditional culture in determining group B streptococcus colonization, Am J Obstet Gynecol. 2007;197(4):388.

25. Picchiassi E, Coata G, Babucci G, et aL. Intrapartum test for detection of Group B Streptococcus colonization during labor. J Matern Fetal Neonatal Med. 2018;31(24):3293-3300. [CrossRef] 